\title{
Keefektifan ekstrak Piper retrofractum Vahl., Anonna squamosa L. dan Tephrosia vogelii Hook. serta campurannya terhadap imago kutu putih pepaya Paracoccus marginatus Williams \& Granara de Willink (Hemiptera: Pseudococcidae)
}

\author{
The effectiveness extract of Piper retrofractum Vahl., \\ Anonna squamosa L., and Tephrosia vogelii Hook. and \\ their mixtures against papaya mealybug Paracoccus marginatus \\ Williams \& Granara de Willink (Hemiptera: Pseudococcidae)
}

\author{
Trijanti A. Widinni Asnan, Dewi Sartiami, Ruly Anwar, Dadang* \\ Departemen Proteksi Tanaman, Fakultas Pertanian, Institut Pertanian Bogor \\ Jalan Kamper, Kampus IPB Dramaga, Bogor 16680
}

(diterima November 2013, disetujui Mei 2014)

\begin{abstract}
ABSTRAK
Paracoccus marginatus Williams \& Granara de Willink (Hemiptera: Pseudococcidae) merupakan hama penting pada tanaman pepaya. Salah satu kendala dalam pengendalian hama ini adalah adanya lapisan lilin yang menutupi tubuh serangga sehingga pengendalian dengan insektisida kurang efektif. Penelitian ini bertujuan mengetahui keefektifan ekstrak Piper retrofractum (Pr), Anonna squamosa (As), dan Tephrosia vogelii (Tv) serta campurannya untuk mengendalikan $P$. marginatus. Setiap ekstrak diuji terhadap imago betina $P$. marginatus dengan metode semprot serangga pada daun dan setiap perlakuan diamati mortalitasnya pada 24, 48, dan 72 jam setelah perlakuan (JSP). Hasil penelitian menunjukkan bahwa pada taraf $\mathrm{LC}_{95}-72 \mathrm{JSP}$, ekstrak Tv dan As 3 kali lebih efektif dibandingkan dengan Pr terhadap imago P. marginatus. Konsentrasi ekstrak tunggal yang efektif untuk mematikan sekitar $95 \%$ populasi $P$. marginatus $\left(\mathrm{LC}_{95}\right)$ adalah $1,250 \%$ (Tv), 1,482\% (Pr), dan 0,469\% (As). Campuran ekstrak Tv + As (2: 1 w/w) dan As + Pr (2: 1 w/w) sekitar 1,67 kali lebih efektif terhadap imago P. marginatus daripada campuran ekstrak Tv + $\operatorname{Pr}(2: 1 \mathrm{w} / \mathrm{w})$. Berdasarkan indeks kombinasi pada pengamatan 72 JSP, campuran ekstrak Tv + As dan Tv + Pr bersifat sinergistik lemah, sedangkan campuran ekstrak As + Pr bersifat aditif. Selain menimbulkan kematian, perlakuan dengan menggunakan semua ekstrak uji juga mengganggu proses pembentukan lilin yang menutupi telur (kantung telur). Dengan demikian, ekstrak Pr, As, dan Tv, serta campurannya pada perbandingan tertentu berpotensi untuk digunakan sebagai salah satu alternatif dalam pengendalian hama P. marginatus karena memiliki toksisitas dan sifat campuran yang cukup baik.
\end{abstract}

Kata kunci: hama pepaya, insektisida nabati, sinergistik lemah

\begin{abstract}
Paracoccus marginatus Williams \& Granara de Willink (Hemiptera: Pseudococcidae) is one of the papaya insect pests that causes high economic loss. The major constraint in controling this pest with insecticides is the existence of wax layer covering the insect body.The objective of this research was to evaluate the effectiveness of Piper retrofractum (Pr), Anonna squamosa (As),
\end{abstract}

\footnotetext{
*Penulis korespondensi: Dadang. Departemen Proteksi Tanaman, Fakultas Pertanian, Institut Pertanian Bogor,

Jalan Kamper Kampus IPB Dramaga, Bogor 16680

Tel: 0251-8629364, Faks: 0251-8629362,Email: dadangtea@ipb.ac.id
} 
and Tephrosia vogelii (Tv) extracts as well as their mixtures to control P. marginatus imago in the laboratory. Pr, As, and Tv extracts were tested separately and in extract mixtures against female P. marginatus by direct spray on the insect. Each treatment was observed at 24, 48, and 72 hours after treatment (HAT). Our result showed that at the LC95 - 72 HAT, Tv and As extracts were about three times more effective to $P$. marginatus than Pr extract. The effective concentration that causing around $95 \%$ mortality of $P$. marginatus are $1.250 \%(\mathrm{Tv}), 1.482 \%(\mathrm{Pr})$, dan $0.469 \%$ (As). Extracts mixtures of $\mathrm{Tv}+\mathrm{As}(2: 1, \mathrm{w} / \mathrm{w})$ and As $+\operatorname{Ps}(2: 1, \mathrm{w} / \mathrm{w})$ were about 1.67 times more effective than $\mathrm{TV}+\operatorname{Pr}(2: 1, \mathrm{w} / \mathrm{w})$ extracts mixtures. Based on combination index at $72 \mathrm{HST}$, extract mixtures of TV + As and Tv + Pr had low sinergistic joint action, meanwhile As + Pr extract mixture had additive joint action. In addition, all the extracts treatments disturbed the formation of the wax coverings the eggs (egg sacs). Pr, As, and Tv extracts as well as their mixtures at certain extract comparison have the alternate potential to control the mealybug $P$. marginatus.

Key words: botanical insecticides, pest of papaya, low sinergistic action

\section{PENDAHULUAN}

Kutu putih Paracoccus marginatus Williams \& Granara de Willink (Hemiptera: Pseudococcidae) merupakan jenis kutu putih yang berperan sebagai serangga hama pada berbagai tanaman di Indonesia. P. marginatus bukan merupakan serangga asli Indonesia melainkan berasal dari Meksiko atau Amerika Tengah. Pada tahun 1992, kutu putih ini dilaporkan berada di wilayah neotropical di Belize, Costa Rica, Guatemala, dan Mexico (Williams \& Granara 1992) dan di Indonesia pertama kali ditemukan berada di wilayah Bogor pada tahun 2008 (Muniappan et al. 2008).

Populasi kutu putih pepaya apabila tidak dikendalikan dapat menyebabkan hasil panen menurun hingga $58 \%$. Jika pengendalian dilakukan akan meningkatkan biaya produksi sebesar $84 \%$ akibat penggunaan pestisida (Ivakdalam 2010). Di negara lain, seperti Ghana, serangan kutu putih papaya menghancurkan sekitar $85 \%$ tanaman pepaya yang dibudidayakan pada tahun 2009 dan 1.734 karyawan disektor ini kehilangan pekerjaan mereka (Offei et al. 2015).

Petani di Indonesia umumnya mengendalikan P. marginatus menggunakan insektsida sintetik, meskipun sebenarnya belum ada jenis pestisida yang terdaftar di Indonesia untuk hama tersebut. Di luar negeri telah dilaporkan bahwa terdapat jenis bahan aktif yang dapat digunakan untuk mengendalikan hama kutu putih pepaya, diantaranya karbaril, klorpirifos, diazinon, dimetoat, dan malation, namun hasil pengendalian kurang efektif dan penggunaan bahan tidak efisien karena aplikasi harus dilakukan berkali-kali dan dengan dosis dua kali lipat dari dosis yang direkomendasikan (Walker et al. 2003). Hal ini diduga terjadi karena $P$. marginatus termasuk jenis kutu-kutuan yang seluruh tubuhnya diselimuti oleh lapisan lilin berwarna putih sehingga cairan insektisida yang diaplikasikan terhalang dan tidak langsung mengenai tubuhnya. Menurut Townsend et al. (2000), secara umum kutu putih sulit untuk dikendalikan secara kimiawi, karena adanya lapisan lilin tebal yang diseksresikan hingga menutupi tubuhnya. Aplikasi insektisida sintetik yang dilakukan berkali-kali dengan dosis yang lebih tinggi sangat tidak efisien dan dapat menimbulkan dampak negatif yang berbahaya terhadap lingkungan serta kesehatan manusia. Untuk itu, diperlukan upaya pengendalian yang lebih efisien, ramah lingkungan, dan aman baik terhadap kesehatan manusia maupun organisme non sasaran. Salah satu alternatif yang dapat digunakan untuk mengurangi penggunaan insektisida sintetik adalah dengan menggunakan insektisida nabati.

Beberapa jenis ekstrak tumbuhan yang diketahui dapat bersifat sebagai insektisida pada $P$. marginatus maupun serangga hama lain adalah Piper retrofractum (cabai jawa), Anonna squamosa (srikaya), Tephrosia vogelii (kacang babi). Menurut Sifa et al. (2013), pengujian ekstrak T. vogelii pada konsentrai $1 \%$ terhadap $P$. marginatus menyebabkan kematian sebesar $84 \%$ dan perlakuan menggunakan ekstrak $A$. squamosa dengan konsentrasi yang sama dapat menyebabkan kematian sebesar $73,3 \%$ pada 72 jam setelah perlakuan. Pola kematian $P$. marginatus akibat perlakuan P. retrofractum tidak jauh berbeda dengan yang diberi perlakuan dengan menggunakan T. vogelii.

Selain digunakan secara tunggal, insektisida nabati juga dapat digunakan dalam bentuk campuran. Penggunaan insektisida nabati dalam bentuk campuran dapat mengefisienkan bahan 
tumbuhan dan mengurangi ketergantungan terhadap satu jenis tumbuhan serta memperlambat laju resistensi (Dadang et al.).

Penelitian ini bertujuan mengetahui keefektifan penggunaan ekstrak tunggal $A$. squamosa, $P$. retrofractum, dan $T$. vogelii, serta masing-masing campurannya dalam mengendalikan kutu putih pepaya $P$. marginatus.

\section{BAHAN DAN METODE}

Penelitian dilaksanakan di Laboratorium Fisiologi dan Toksikologi Serangga dan Laboratorium Biosistematika Serangga, Departemen Proteksi Tanaman, Fakultas Pertanian, Institut Pertanian Bogor. Penelitian dilaksanakan mulai dari bulan Oktober 2012 sampai dengan bulan Juli 2013.

\section{Penanaman dan pemeliharaan tanaman pepaya}

Bibit pepaya yang digunakan diperoleh dari petani di Kecamatan Rancabungur Kabupaten Bogor, yang merupakan bibit pepaya varietas IPB 9. Bibit yang berumur 2 minggu disemaikan di polybag bening berukuran $5 \mathrm{~cm} \times 10 \mathrm{~cm}$ sebanyak 2 tanaman per polybag. Setelah bibit pepaya berumur 1 bulan, kemudian dipindahkan pada polybag hitam berukuran $25 \mathrm{~cm}$ x $25 \mathrm{~cm}$ sebanyak 1 bibit per polybag dengan media tanam berupa campuran antara tanah dan kompos 1: 1 (w/w). Pemeliharaan bibit pepaya dilakukan setiap hari yang meliputi penyiraman, penyiangan dan pengendalian hama lain dilakukan secara mekanis.

\section{Identifikasi dan perbanyakan serangga uji}

Sebelum dilakukan perbanyakan serangga uji terlebih dahulu dilakukan identifikasi untuk memastikan bahwa serangga yang digunakan adalah $P$. marginatus. Serangga yang didapatkan dari lapangan dibuat menjadi preparat slide dan kemudian diindentifikasi. Identifikasi dilakukan di bawah mikroskop dengan memperhatikan bentuk morfologi dan mengacu pada buku Mealybugs of Central and South America (Williams \& Granara 1992).

Serangga yang telah diidentifikasi, dipelihara dan diperbanyak pada bibit pepaya yang berumur 2 bulan atau tinggi tanaman $\pm 25-30 \mathrm{~cm}$. Tanaman pepaya disungkup dengan plastik silindris yang bagian atasnya berupa kasa. Untuk menghindari serangan predator ataupun organisme pengganggu lain. Serangga P. marginatus dibiarkan berkembang biak agar mencapai jumlah yang mencukupi untuk digunakan dalam pengujian.

\section{Penyiapan insektisida nabati}

Buah $P$. retrofractum, daun $T$. vogelii, dan biji $A$. squamosa dipotong kecil-kecil, kemudian dikeringanginkan di dalam ruangan. Bahan tumbuhan tersebut kemudian dihaluskan dengan menggunakan blender hingga berbentuk serbuk dan diayak hingga mendapatkan serbuk yang berukuran relatif seragam. Ekstraksi dilakukan dengan metode maserasi. Setiap serbuk tumbuhan dimasukkan ke dalam labu Erlenmeyer, kemudian ditambahkan metanol $(1: 10 \mathrm{w} / \mathrm{v})$ hingga seluruh bahan terendam, lalu disimpan selama 48 jam. Rendaman masing-masing bahan tumbuhan disaring dengan menggunakan corong kasa yang dialasi kertas saring. Hasil saringan diuapkan menggunakan rotary evaporator pada suhu $50{ }^{\circ} \mathrm{C}$ dan tekanan 337 mbar hingga diperoleh ekstrak kasar. Setiap ekstrak yang diperoleh disimpan dalam lemari pendingin pada suhu $\pm 4{ }^{\circ} \mathrm{C}$ hingga saat digunakan.

\section{Uji ekstrak tunggal}

Pengujian dilakukan dengan menggunakan rancangan acak lengkap (RAL). Masing-masing ekstrak kasar diencerkan dengan larutan metanol dan Tween $(5: 1 \mathrm{v} / \mathrm{v})$ dan akuades. Perlakuan untuk masing-masing ekstrak menggunakan lima taraf konsentrasi, yaitu $0,01 \%, 0,1 \%, 0,5 \%, 1 \%$, dan $3 \%$ ditambah kontrol. Setiap perlakuan diulang sebanyak lima kali. Metode yang digunakan pada pengujian ini, yaitu semprot serangga pada daun. Sebanyak 10 imago P. marginatus disimpan di atas cawan petri yang telah dialasi tisu berwarna hijau dan daun pepaya sebagai pakan yang bagian ujungnya telah diberi kapas basah. Sediaan ekstrak kemudian disemprotkan pada imago sebanyak 3 semprotan untuk setiap ulangan volume $\pm 0,4 \mathrm{ml}$ menggunakan hand sprayer.

Daun beserta imago yang telah disemprot dipindahkan ke cawan lain yang juga telah dialasi kertas tisu hijau untuk menghindari kelembapan yang terlalu tinggi pada cawan Petri akibat kertas tisu yang basah terkena cairan ekstrak.

Pengamatan dilakukan pada 24, 48, dan 72 jam setelah perlakuan (JSP) dengan menghitung 
jumlah $P$. marginatus yang mati. Hasil pengujian dianalisis dengan menggunakan program POLO PC (LeOra Software 1987) untuk mengetahui konsentrasi yang dapat mematikan $50 \%$ serangga uji $\left(\mathrm{LC}_{50}\right)$ dan $\mathrm{LC}_{95}$ pada pengamatan 24,48 , dan 72 JSP untuk masing masing ekstrak dan perbandingan nilai tengah antar perlakuan dilakukan dengan uji Duncan dengan taraf nyata 5\%.

\section{Uji campuran ekstrak}

Ekstrak yang digunakan, yaitu A. squamosa (As), P. retrofractum (Pr), dan T. vogelii (Tv) masing-masing dikombinasikan sehingga menghasilkan campuran ekstrak As $+\mathrm{Pr}, \mathrm{Tv}+\mathrm{As}$, dan $\mathrm{Tv}+\operatorname{Pr}$ dengan perbandingan masing-masing campuran $1: 2,2: 1$, dan $1: 1(\mathrm{w} / \mathrm{w})$. Setiap campuran diencerkan dengan menggunakan metanol dan Tween $(5: 1)$ hingga mendapatkan 6 taraf konsentrasi yang berbeda. Konsentrasi yang digunakan untuk masing-masing campuran dan perbandingan didapatkan dari hasil analisis $\mathrm{LC}_{95}$ -72 JSP pada uji tunggal masing-masing ekstrak.

Pengamatan dilakukan pada 24, 48, dan 72 JSP terhadap mortalitas serangga. Pengujian dilakukan dengan menggunakan RAL. Data hasil pengamatan tersebut kemudian diolah dengan menggunakan program POLO PC (LeOra Software 1987) untuk menentukan nilai $\mathrm{LC}_{50}$ dan $\mathrm{LC}_{95}$, sehingga dapat ditentukan nilai indeks kombinasi campuran (IK) pada taraf $\mathrm{LC}_{\mathrm{x}}$ dari masing-masing kombinasi yang dihitung dengan menggunakan rumus:

$$
\mathrm{IK}=\frac{\mathrm{LC}_{\mathrm{x}}{ }^{\mathrm{a}(\mathrm{mj})}}{\mathrm{LC}_{\mathrm{x}}^{\mathrm{a}}}+\frac{\mathrm{LC}_{\mathrm{x}}^{\mathrm{b}(\mathrm{mj})}}{\mathrm{LC}_{\mathrm{x}}^{\mathrm{b}}}+\frac{\mathrm{LC}_{\mathrm{x}}{ }^{\mathrm{a}(\mathrm{mj})}}{\mathrm{LC}_{\mathrm{x}}^{\mathrm{a}}}+\frac{\mathrm{LC}_{\mathrm{x}}{ }^{\mathrm{a}(\mathrm{mj})}}{\mathrm{LC}_{\mathrm{x}}^{\mathrm{b}}}
$$

$\mathrm{LC}_{\mathrm{x}}{ }^{\mathrm{a}(\mathrm{mj})}$ dan $\mathrm{LC}_{\mathrm{x}}{ }^{\mathrm{b}(\mathrm{mj})}$ merupakan $\mathrm{LC}_{\mathrm{x}}$ percobaan campuran dikalikan proporsi konsentrasi dalam campuran tersebut yang mengakibatkan mortalitas $\mathrm{x}(5 \%-95 \%)$, sedangkan $\mathrm{LC}_{\mathrm{x}}{ }^{\mathrm{a}}$ dan $\mathrm{LC}_{\mathrm{x}}{ }^{\mathrm{b}}$ merupakan ekstrak tunggalnya (Chou \& Talalay 1984). Uji nilai tengah berganda dilakukan dengan Program SAS 9.0.

\section{HASIL}

\section{Identifikasi serangga uji}

Serangga uji yang didapatkan dari lapangan sesuai dengan ciri morfologi $P$. marginatus yang dikemukakan oleh Williams \& Granara (1992). Permukaan tubuh kutu ini ditutupi oleh lilin berwarna putih yang merupakan hasil sekresi dari tubuhnya. Imago betina memiliki panjang tubuh $2,5 \mathrm{~mm}$. Panjang antena kurang lebih 310 $370 \mu \mathrm{m}$ dengan jumlah segmen 8 . Pada bagian tepi terdapat rangkaian filamen lilin pendek di sepanjang bagian tepi tubuh dan terdapat kantung telur (ovisac) di bagian posterior tubuh betina dewasa. Menurut Miller \& Miller (2002) kantung telur dibentuk di bagian ventral posterior tubuh betina dewasa.

\section{Toksisitas ekstrak $P$. retrofractum, $A$. squamosa,} dan $T$. vogelii terhadap imago $P$. marginatus

Ekstrak tunggal. Secara umum, ketiga jenis ekstrak yang digunakan mampu mengakibatkan mortalitas $P$. marginatus hingga lebih dari 50\% pada konsentrasi diatas $0,01 \%$. Konsentrasi tertinggi yang digunakan untuk setiap ekstrak, yaitu $3 \%$, pada ekstrak $T$. vogelii, P. retrofractum, dan $A$. squamosa dapat mengakibatkan mortalitas imago P. marginatus secara berturut-turut sebesar $98 \%$, $100 \%$, dan $100 \%$, sedangkan pada konsentrasi terendah yang digunakan, yaitu $0,01 \%$ untuk masing-masing ekstrak hanya mampu mengakibatkan mortalitas imago $P$. marginatus secara berturut-turut sebesar $46 \%$, 62\%, dan $18 \%$ pada 72 JSP (Gambar 1). Tiap jenis ekstrak mampu menimbulkan kematian imago P. marginatus sejak hari pertama perlakuan meskipun konsentrasi yang diaplikasikan rendah dan mortalitas imago $P$. marginatus terus meningkat hingga pengamatan pada hari ke-3 atau pada 72 JSP. Perlakuan kontrol yang hanya menggunakan metanol dan Tween (5 : 1) dan akuades tidak mengakibatkan kematian hingga pengamatan ke-3 pada 72 JSP. Hal ini menunjukkan bahwa pelarut yang digunakan tidak memberikan pengaruh buruk terhadap imago $P$. marginatus.

Konsentrasi efektif yang dapat mematikan imago P. marginatus sebesar $95 \%$ untuk perlakuan dengan menggunakan ekstrak $T$. vogelii, $P$. retrofractum dan $A$. squamosa berturut-turut adalah sebesar $1,250 \%, 1,482 \%$, dan $0,469 \%$, sedangkan konsentrasi efektif yang dapat mematikan imago $P$. marginatus hingga 50\% untuk masing-masing ekstrak berturut-turut adalah sebesar $0,020 \%$, $0,007 \%$, dan $0,042 \%$ pada 72 JSP (Tabel 1 ).

Gejala yang terlihat setelah perlakuan dengan metode semprot serangga pada daun adalah adanya lilin-lilin baru yang muncul pada 72 JSP setelah sebelumnya sempat meluruh akibat perlakuan, namun lilin yang baru muncul ini bentuknya tidak 
beraturan dan menggumpal-gumpal (Gambar 2A), Gejala lainnya adalah terganggunya pembentukan kantung telur. Telur-telur yang muncul setelah imago mengalami perlakuan tidak ditutupi oleh kantung telur berwarna putih (Gambar 2B). Kantung telur tersebut merupakan bentuk perlindungan yang diberikan oleh imago betina P. marginatus terhadap telur yang diletakkan oleh imago agar telur-telur tersebut terlindung dari berbagai ancaman. Selain itu, pada serangga uji yang mati terjadi perubahan warna tubuh menjadi lebih gelap, yaitu coklat pada awal pengamatan kemudian berubah menjadi kehitaman serta mengering pada akhir pengamatan (Gambar 2C). Seluruh gejala ini muncul pada setiap perlakuan esktrak dan bukan merupakan gejala yang spesifik dari satu jenis ekstrak tanaman yang digunakan.

Ekstrak campuran. Persentase mortalitas tertinggi pada campuran ekstrak $\mathrm{Tv}+$ As terdapat pada perbandingan $1: 2$ dan $2: 1$ dengan konsentrasi
$0,6 \%$, yaitu sebesar $98 \%$ sedangkan mortalitas pada konsentrasi $0,6 \%$ dengan perbandingan $1: 1$ hanya sebesar $94 \%$. Persentase mortalitas imago $P$. marginatus terendah yang diakibatkan oleh perlakuan ekstrak campuran dengan konsentrasi $0,025 \%$ dengan perbandingan $1: 2,2: 1$, dan $1: 1$ masing-masing sebesar $36 \%, 42 \%$, dan $24 \%$ (Gambar 3).

Berbeda dengan campuran ekstrak $\mathrm{Tv}+\mathrm{As}$, taraf konsentrasi yang digunakan pada campuran esktrak Tv + Pr untuk setiap perbandingan tidak sama. Pada perbandingan 1:2 taraf konsentrasi yang digunakan adalah $0,062 \%, 0,125 \%, 0,25 \%$, $0,5 \%, 1 \%$, dan $1,2 \%$, sedangkan taraf konsentrasi yang digunakan pada perbandingan $2: 1$ adalah $0,05 \%, \quad 0,1 \%, 0,2 \%, 0,4 \%, 0,8 \%$, dan $1 \%$ sedangkan untuk taraf konsentrasi yang digunakan pada perbandingan $1: 1$ adalah $0,056 \%, 0,1125 \%$, $0,225 \%, 0,45 \%, 0,9 \%$, dan $1,1 \%$. Persentase mortalitas imago $P$. marginatus tertinggi diakibatkan oleh perlakuan dengan konsentrasi tertinggi pada
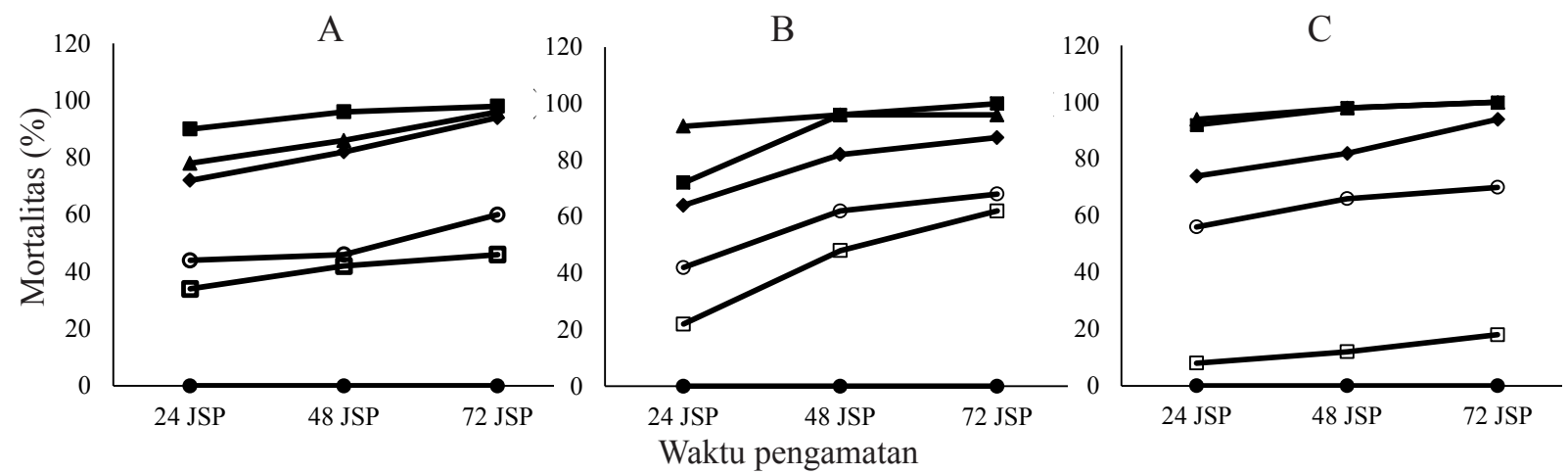

Gambar 1. Perkembangan tingkat mortalitas imago Paracoccus marginatus akibat perlakuan ekstrak Tephrosia

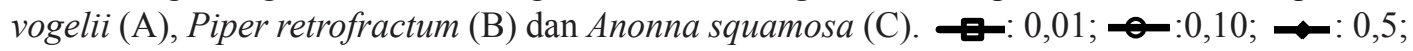
$\rightarrow: 1 ; \rightarrow-3 ; \rightarrow$ : kontrol.

Tabel 1. Toksisitas tiga jenis ekstrak Tephrosia vogelii, Anonna squamosa, dan Piper retrofractum terhadap mortalitas imago betina Paracoccus marginatus

\begin{tabular}{lcccll}
\hline Jenis ekstrak & $\begin{array}{c}\text { Waktu pengamatan } \\
\left(\mathrm{JSP}^{\mathrm{c}}\right)\end{array}$ & $a \pm \mathrm{GB}^{\mathrm{a}}$ & $b \pm \mathrm{GB}^{\mathrm{a}}$ & \multicolumn{1}{c}{$\mathrm{LC}_{50}^{\mathrm{b}}(\%)$} & \multicolumn{1}{c}{$\mathrm{LC}_{95}(\%)$} \\
\hline T. vogelii & 24 & $1,079 \pm 0,110$ & $0,677 \pm 0,102$ & $0,071(0,012-0,191)$ & $18,968(3,390-2510,597)$ \\
& 48 & $1,074 \pm 0,123$ & $0,745 \pm 0,107$ & $0,036(-)$ & $5,823(-)$ \\
& 72 & $1,556 \pm 0,159$ & $0,913 \pm 0,123$ & $0,020(0,0003-0,073)$ & $1,250(0,291-316,521)$ \\
P. retrofractum & 24 & $0,623 \pm 0104$ & $0,696 \pm 0,102$ & $0,127(-)$ & $29,395(-)$ \\
& 48 & $1,299 \pm 0,137$ & $0,745 \pm 0,011$ & $0,018(0,0003-0,067)$ & $2,905(0,611-788,815)$ \\
& 72 & $1,524 \pm 0,156$ & $0,707 \pm 0,122$ & $0,007(-)$ & $1,482(-)$ \\
A. squamosa & 24 & $1,158 \pm 0,129$ & $1,184 \pm 0,128$ & $0,105(0,029-0,245)$ & $2,574(0,874-33,56)$ \\
& 48 & $1,592 \pm 0,163$ & $1,338 \pm 0,142$ & $0,065(0,241-0,129)$ & $1,095(0,466-5,718)$ \\
& 72 & $2,159 \pm 0,233$ & $1,565 \pm 0,174$ & $0,042(0,294-0,9000$ & $0,469(0,260-1,181)$ \\
\hline
\end{tabular}

${ }^{\mathrm{a}} a$ : intersep regresi probit; $b$ : kemiringan regresi probit; GB: galat baku; ${ }^{\mathrm{b} L C}$ : lethal concentration; ${ }^{\mathrm{c} J S P}$ : jam setelah perlakuan. 

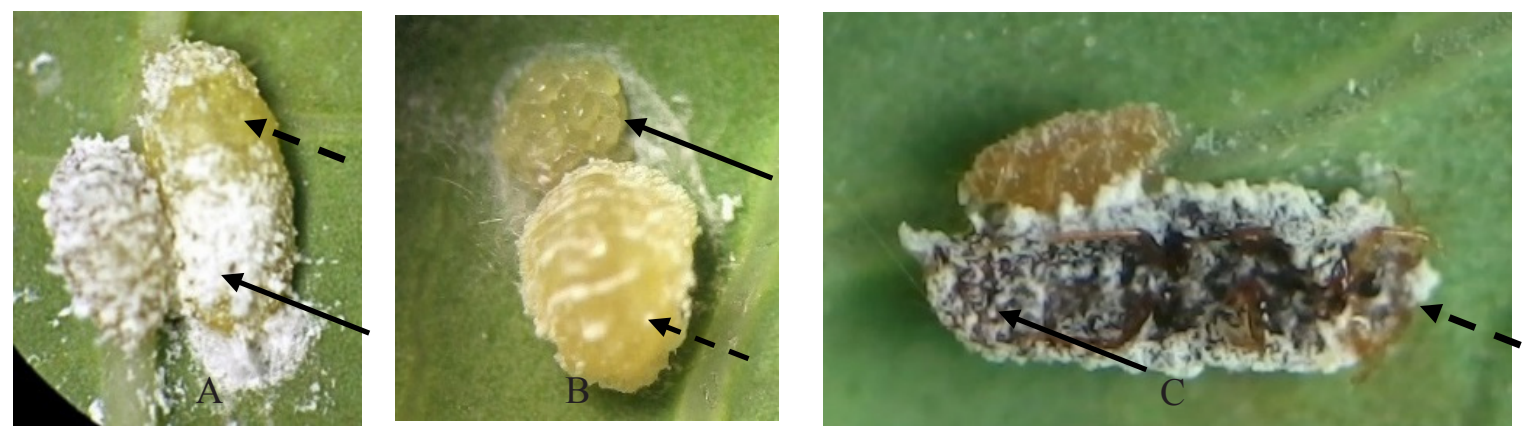

Gambar 2. Gejala yang terjadi akibat perlakuan beberapa jenis insektisida nabati pada pengamatan 72 jam setelah perlakuan (JSP). $\rightarrow$ : gejala; $\boldsymbol{\longrightarrow} \rightarrow$ : bagian anterior serangga.
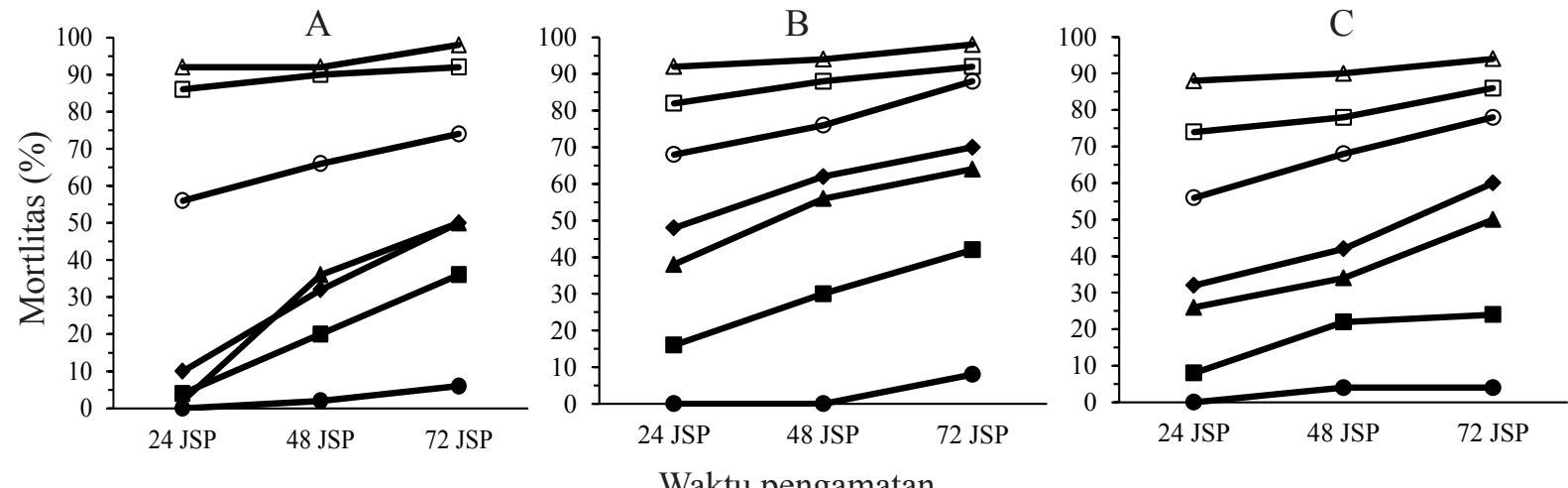

Gambar 3. Perkembangan tingkat mortalitas imago Paracoccus marginatus akibat perlakuan ekstrak campuran Tephrosia vogelii + Anonna squamosa perbandingan $1: 2$ (A), $2: 1$ (B), dan $1: 1$ (C). - $\rightarrow$ - kontrol; $\rightarrow: 0,025 ; \rightarrow: 0,05 ; \rightarrow: 0,1 ; \rightarrow: 0,2 ; \rightarrow: 0,4 ; \multimap: 0,6$.

masing-masing perbandingan, yaitu berturut-turut untuk perbandingan $1: 2,2: 1$, dan $1: 1$ adalah sebesar 96\%, 98\%, dan 92\% dan untuk persentase mortalitas imago $P$. marginatus terendah pada masing-masing perbandingan diakibatkan oleh perlakuan dengan konsentrasi terendah, yaitu berturut-turut untuk perbandingan $1: 2,2: 1$ dan 1 : 1 adalah sebesar 22\%, 36\%, dan 32\% (Gambar 4).

Taraf konsentrasi yang digunakan pada campuran ekstrak As + Pr sama dengan taraf konsentrasi yang digunakan pada campuran $\mathrm{Tv}+\operatorname{Pr}$ untuk setiap perbandingannya. Persentase mortalitas imago $P$. marginatus tertinggi pada ekstrak campuran $\mathrm{Tv}+\operatorname{Pr}$ adalah sebesar $100 \%$ yang diakibatkan oleh perlakuan dengan konsentrasi tertinggi pada perbandingan $1: 2$ dan $2: 1$, sedangkan persentase mortalitas imago $P$. marginatus yang ditimbulkan oleh konsentrasi tertinggi pada perbandingan $1: 1$ hanya sebesar $94 \%$. Persentase mortalitas imago $P$. marginatus terendah pada masing-masing perbandingan diakibatkan oleh perlakuan dengan konsentrasi terendah, yaitu berturut-turut untuk perbandingan $1: 2,2: 1$, dan $1: 1$ adalah sebesar 54\%, $60 \%$, dan 38\% (Gambar 5).
Berdasarkan data-data tersebut, terlihat bahwa perbandingan $2: 1(\mathrm{w} / \mathrm{w})$ pada setiap campuran ekstrak lebih efektif dibandingan dengan perbandingan $1: 2$ dan $1: 1(\mathrm{w} / \mathrm{w})$. Efektifitas campuran ekstrak pada perbandingan $2: 1$ juga terlihat pada hasil analisis toksisitas antar perbandingan pada masingmasing ekstrak. Nilai $\mathrm{LC}_{95}$ pada 72 JSP campuran ekstrak Tv +As dengan perbandingan $1: 2,2: 1$, dan $1: 1(\mathrm{w} / \mathrm{w})$ berturut-turut adalah sebesar $0,743 \%$, $0,498 \%$, dan $0,743 \%$, sedangkan campuran ekstrak $\mathrm{Tv}+\operatorname{Pr}$ berturut-turut sebesar 1,128\%, 0,832\%, dan $1,707 \%$ dan untuk campuran ekstrak As + Pr berturut-turut sebesar $0,773 \%, 0,500 \%$, dan $1,527 \%$. Sehingga perbandingan 2: $1(\mathrm{w} / \mathrm{w})$ lebih efektif sekitar 1,49 kali pada campuran $\mathrm{Tv}+\mathrm{As}$, 2,05 kali pada campuran $\mathrm{Tv}+\mathrm{Pr}$, dan 2,3 kali pada campuran As + Pr daripada perbandingan $1: 2$ dan $1: 1$ untuk masing-masing ekstrak (Tabel 2).

\section{Sifat aktivitas campuran ekstrak $P$. retrofractum, $A$. squamosa, dan $T$. vogelii terhadap imago $P$. marginatus}

Sifat interaksi pada masing-masing perbandingan untuk setiap campuran berbeda-beda 
A

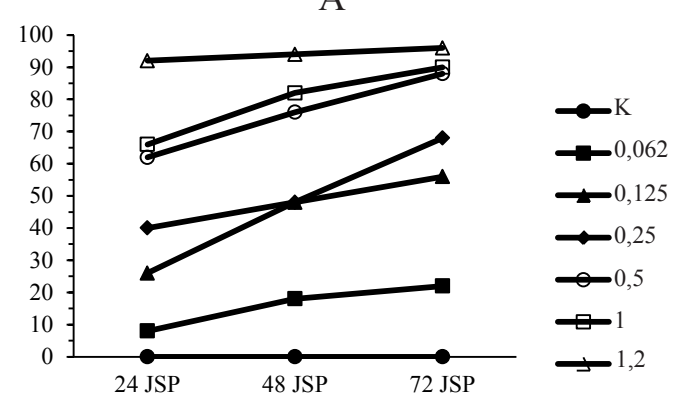

$\mathrm{B}$

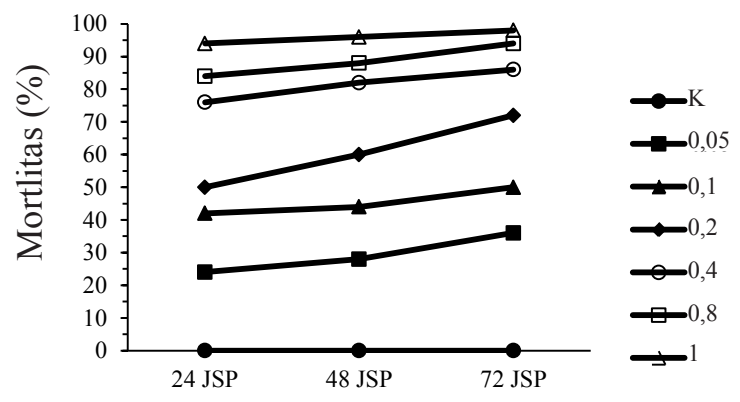

C

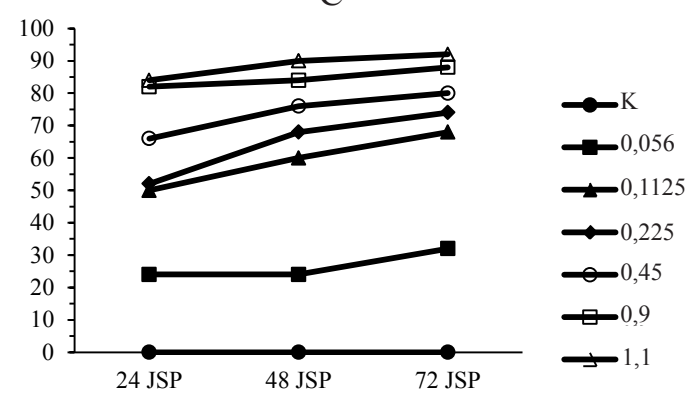

Waktu pengamatan

Gambar 4. Perkembangan tingkat mortalitas imago Paracoccus marginatus akibat perlakuan ekstrak campuran Tephrosia vogelii + Piper retrofractum perbandingan $1: 2(\mathrm{~A}), 2: 1(\mathrm{~B})$, dan $1: 1(\mathrm{C})$. $\rightarrow:$ Kontrol; $\rightarrow-: 0,05 ; \rightarrow 0,11$;

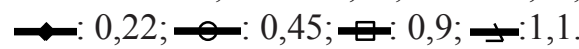

berdasarkan indeks kombinasi $\mathrm{LC}_{95}$ pada $72 \mathrm{JSP}$. Sifat interaksi campuran ekstrak $\mathrm{Tv}+$ As dan $\mathrm{Tv}+\operatorname{Pr}$ pada perbandingan $1: 2,2: 1$, dan $1: 1$ terhadap imago $P$. marginatus berturut-turut adalah antagonis, sinergistik lemah, dan antagonis. Sementara itu, sifat interaksi campuran ekstrak As + Pr pada perbandingan $1: 2,2: 1$, dan $1: 1$ berturut-turut adalah aditif, aditif, dan antagonis (Tabel 3). Sifat antagonis menunjukkan bahwa tingkat mortalitas imago $P$. marginatus akibat perlakuan tunggal lebih tinggi dibandingkan dengan perlakuan campuran, sementara sifat aditif menunjukkan bahwa tingkat mortalitas imago $P$.
A

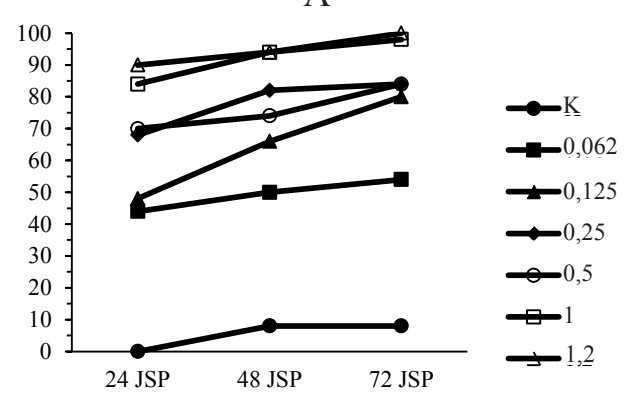

$\mathrm{B}$

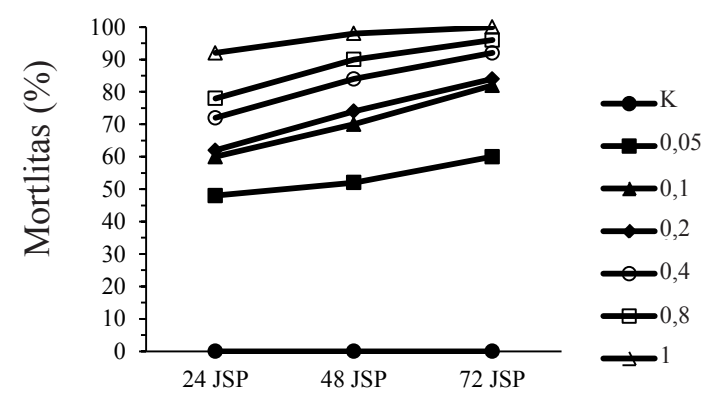

$\mathrm{C}$

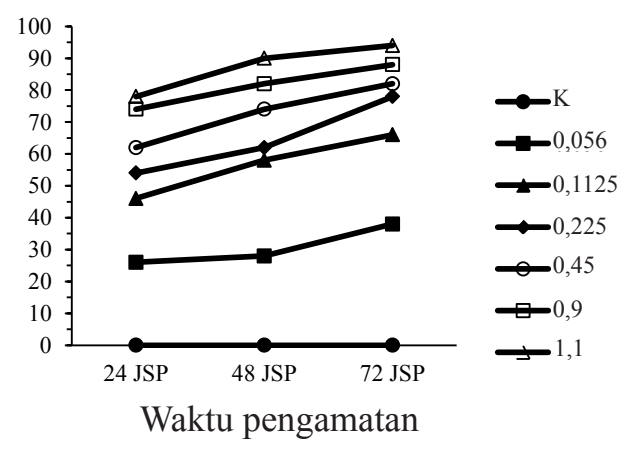

Gambar 5. Perkembangan tingkat mortalitas imago Paracoccus marginatus akibat perlakuan ekstrak campuran Anonna squamosa + Piper retrofractum perbandingan $1: 2(\mathrm{~A}), 2: 1$ (B), dan $1: 1$ (C).

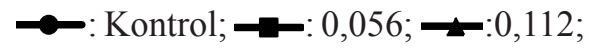

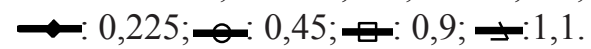

marginatus akibat perlakuan tunggal sama dengan tingkat mortalitas akibat perlakuan campuran dan sifat sinergistik lemah menunjukkan bahwa tingkat mortalitas akibat perlakuan campuran sedikit lebih tinggi dibandingkan dengan tingkat mortalitas imago P. marginatus akibat perlakuan tunggal.

\section{PEMBAHASAN}

Ekstrak $P$. retrofractum, A. squamosa, dan T. vogelii yang digunakan dalam penelitian menunjukkan keefektifan yang cukup baik dalam 


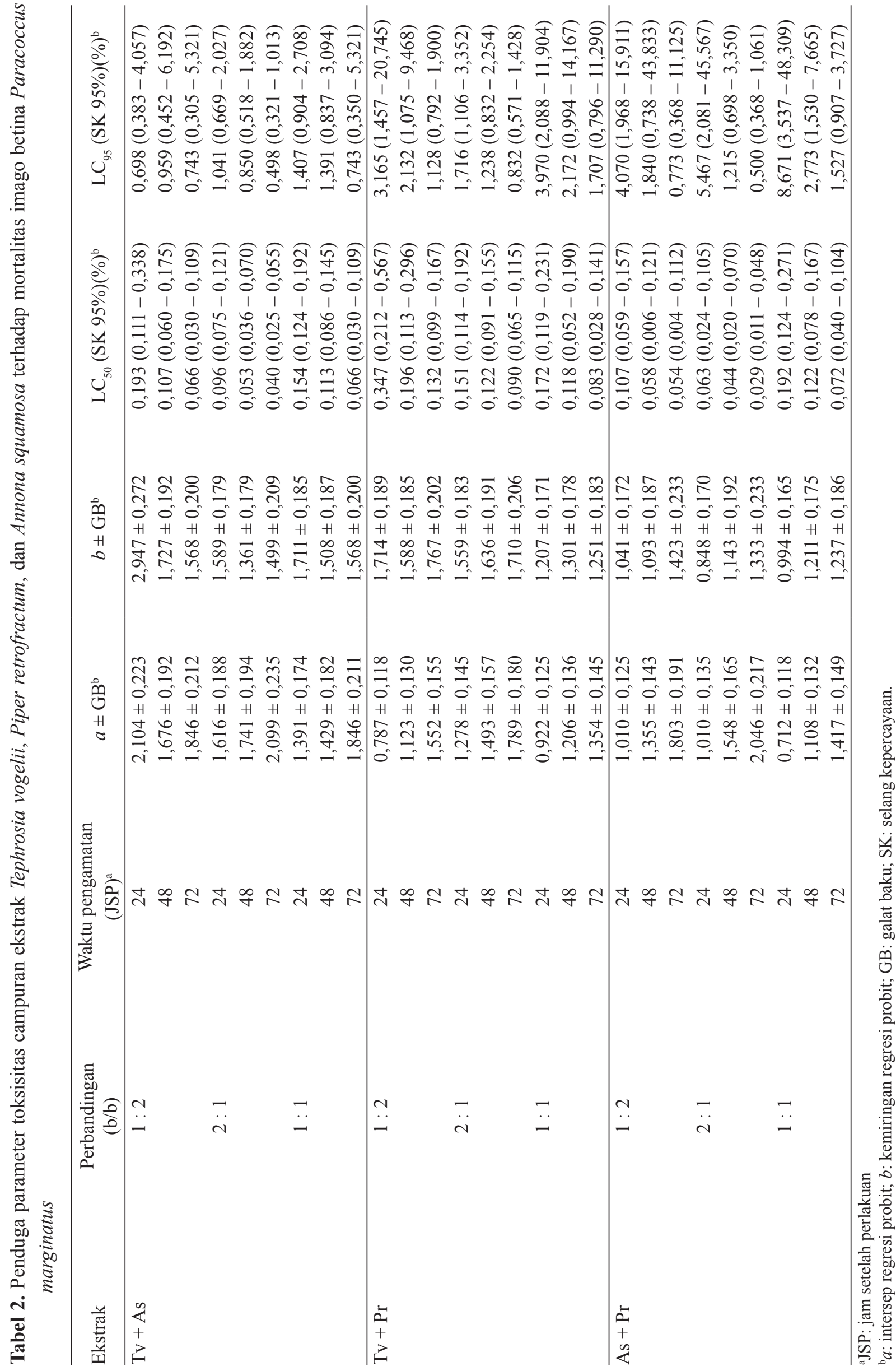


Jurnal Entomologi Indonesia, Juli 2015, Vol. 12, No. 2, 80-90

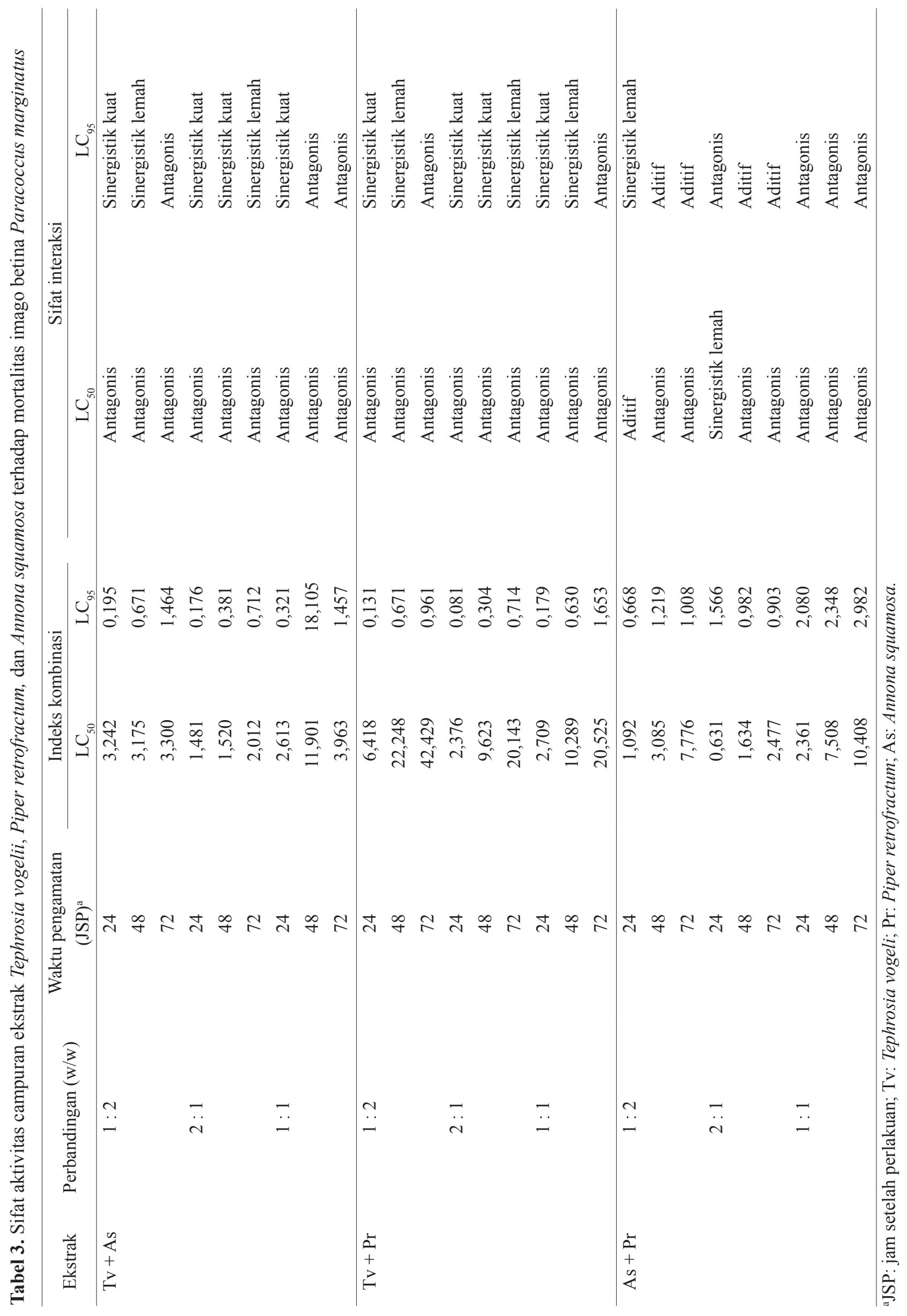


mengendalikan imago $P$. marginatus secara tunggal. Urutan keefektifan ketiga jenis ekstrak dari yang paling efektif hingga kurang efektif untuk mematikan 95\% imago P. marginatus, yaitu A. squamosa pada konsentrasi $0,469 \%, T$. vogelii pada konsentrasi $1,250 \%$, dan terakhir adalah $P$. retrofractum pada konsentrasi $1,482 \%$. Berdasarkan analisis $\mathrm{LC}_{95}-72 \mathrm{JSP}$, ekstrak $A$. squamosa 2,66 kali lebih efektif terhadap imago $P$. marginatus dibandingkan dengan ekstrak $T$. vogelii dan 3,16 kali dibandingkan dengan ekstrak P. retrofractum.

Perbedaan tingkat keefektifan dari setiap ekstrak ini teradi karena adanya perbedaan cara kerja dari masing-masing ekstrak. Senyawa aktif utama yang terkandung dalam $A$. squamosa adalah squamosin dan amisin yang termasuk golongan asetogenin (Saha 2011). Asetogenin ini memiliki cara kerja yang sama seperti rotenon, yaitu melakukan penghambatan pada proses respirasi sel. Rotenon merupakan salah satu senyawa aktif yang terkandung dalam ekstrak $T$. vogelii selain deguelin. Rotenon bekerja sebagai racun respirasi sel, yaitu menghambat transfer elektron dalam NADH-koenzim ubiquinon reduktase (kompleks I) pada sistem transpor elektron yang terjadi di dalam mitokondria. Selain itu, rotenon menyekat pemindahan elektron dari $\mathrm{Fe}-\mathrm{S}$ ke koenzim ubiquinon yang mengakibatan terhambatnya proses respirasi sel dan menurunkan produksi ATP yang merupakan sumber energi, sehingga aktivitas sel akan terhambat dan mengakibatkan serangga menjadi lumpuh dan mati (Hollingworth 2001).

Senyawa aktif yang terkandung dalam ekstrak P. retrofractum termasuk kedalam kelompok piperamida yang memiliki dua aktivitas biologi, yaitu kelompok senyawa yang mengandung gugus metilendioksifenil yang bekerja sebagai penghambat enzim sitokrom P450 (Scott et al. 2008). Enzim ini berperan dalam mengoksidasi berbagai jenis senyawa racun dari luar tubuh dan limbah metabolisme di dalam tubuh, sehingga apabila aktivitasnya terganggu dapat menekan penguraian senyawa racun dalam tubuh serangga tersebut.

Campuran masing-masing ekstrak pada setiap perbandingannya memiliki sifat aktivitas yang berbeda-beda pada taraf $\mathrm{LC}_{95}$ pada 24,48 , dan 72 JSP. Sifat aktivitas campuran ekstrak As + Pr pada 24,48 , dan 72 JSP dalam perbandingan $1: 2$ berturut- turut adalah sinergis lemah, aditif, dan aditif, pada perbandingan $2: 1$ berturut-turut antagonis, aditif, anditif, sedangkan perbanding $1: 1$ seluruhnya antagonis. Sementara sifat campuran $\mathrm{Tv}+\mathrm{Pr}$ dalam perbandingan $1: 2$ dan $1: 1$ sama dengan sifat perbandingan $\mathrm{Tv}+$ As dalam perbandingan $1: 2$, yaitu sinergistik kuat, sinergistik lemah dan antagonis, sedangkan sifat campuran $\mathrm{Tv}+\operatorname{Pr}$ dan $\mathrm{Tv}+$ As dalam perbandingan $2: 1$ adalah sinergistik kuat, sinergistik kuat dan sinergistik lemah, dan sifat campuran ekstrak Tv + As pada perbandingan $1: 1$ adalah sinergistik kuat, antagonis, antagonis.

Sifat campuran dari masing-masing ekstrak cenderung berubah pada setiap waktu pengamatan. Hal ini menunjukkan bahwa campuran tersebut belum stabil apabila digunakan pada taraf $\mathrm{LC}_{95}$ sedangkan taraf $\mathrm{LC}_{50}$ pada setiap campuran ekstrak cenderung lebih stabil, terlihat dari sifat aktivitas campurannya yang cenderung sama, yaitu antagonis. Sementara itu, menurut Scott et. al (2008), ekstrak Piper spp. yang mengandung senyawa yang memiliki gugus metilendioksifenil dapat bersifat sinergis bila dicampurkan dengan ekstrak tumbuhan lain. Pada penelitian ini ekstrak $P$. retrofractum bersifat sinergis ketika dicampur dengan $A$. squamosa dan $T$. vogelii dalam perbandingan tertentu sehingga dalam mencampurkan ekstrak perlu diperhatikan perbandingan yang digunakan, karena dapat mempengaruhi kerja ekstrak terhadap sasaran.

\section{KESIMPULAN}

Ekstrak $P$. retrofractum, T. vogelii, dan $A$. squamosa efektif bila diaplikasikan secara tunggal pada imago P. marginatus dan dapat mematikan 95\% imago, masing-masing pada konsentrasi $1,250 \%$ (Tv), 1,482\% (Pr), dan 0,469\% (As). Campuran ekstrak Tv $+\operatorname{Pr}, \mathrm{Tv}+\mathrm{As}$, dan $\mathrm{Pr}+\mathrm{As}$ memiliki sifat aktivitas yang berbeda pada masingmasing perbandingan. Sifat aktivitas terbaik pada taraf $\mathrm{LC}_{95}-72$ JSP untuk campuran ekstrak Tv + $\operatorname{Pr}, \mathrm{Tv}+\mathrm{As}$, dan $\mathrm{Pr}+\mathrm{As}$ terdapat pada perbandingan $2: 1(\mathrm{w} / \mathrm{w})$. Campuran ekstrak Tv $+\operatorname{As}(2: 1, \mathrm{w} / \mathrm{w})$, As $+\operatorname{Pr}(2: 1, \mathrm{w} / \mathrm{w})$, dan ekstrak Tv $+\operatorname{Pr}(2: 1$, w/w) efektif pada konsentrasi 0,498\%, 0,500\%, dan $0,832 \%$. Ekstrak P. retrofractum, T. vogelii, dan A. squamosa, serta campuran ekstrak As $+\mathrm{Pr}$, $\mathrm{Tv}+\mathrm{Pr}$, dan $\mathrm{Tv}+$ As berpotensi untuk digunakan 
sebagai salah satu alternatif dalam pengendalian hama $P$. marginatus, karena memiliki hasil analisis toksisitas dan sifat interaksi campuran yang cukup baik.

\section{UCAPAN TERIMA KASIH}

Terima kasih kepada Direktorat Penelitian dan Pengabdian Kepada Masyarakat Direktorat Pendidikan Tinggi, Kementerian Pendidikan dan Kebudayaan atas dukungan dana pada penelitian ini melalui kontrak penelitian No.170/IT3.41.2/ L2/SPK/2013 tanggal 15 Mei 2013.

\section{DAFTAR PUSTAKA}

Chou TC, Talalay P. 1984. Quantitative analysis of dose-effect relationships: the combined effects of multiple drugs or enzyme inhibitors. Advancesin Enzyme Regulation 22:27-55. doi: http://dx.doi. org/10.1016/0065-2571(84)90007-4.

Dadang, Yunia N, Ohsawa K. 2007. Insecticidal activity of extract mixtures of four plant species against Croccidolomia pavonana (F.) (Leidoptera: Pyrallidae) larvae. Journal of ISSAAS 13:9-17.

Hollingworth RM. 2001. Inhibitors and uncouplers of mitrochondrial oxidative phosphorylation. In: Krieger R, Doull J, Ecobichon D, Gammon D, Hdgson et al., (Eds.), Handbook of Pesticide Toxicology, Vol 2. pp. 1169-1227. San Diego: Academic Press.

Ivakdalam ML. 2010. Dampak Ekonomi Serangan Hama Asing Invasif Paracoccus marginatus (Hemiptera: Pseudococcidae) pada Usaha Tani Papaya di Kabupaten Bogor. Tesis. Bogor: Institut Pertanian Bogor.

LeOra Software. 1987. POLO-PC User's Guide. Petaluma: LeOra Software.

Miller DR, Miller GL. 2002. Redescription of Paracoccus marginatus Williams and Grana de Willink (Hemiptera: Coccidea: Pseudococcidae), including description of the immaturestages and adult male. Proceedings of the Entomological Society of Washington 104:1-23.

Muniappan R, Shepard BM, Watson GW, Carner GR, Sartiami D, Rauf A, Hammig MD. 2008. First report of the papaya melybug, Paracoccus marginatus (Hemiptera: Pseudococcidae), in Indonesia and India. Journal of Agricultural and Urban Entomology 25:37-40.

Offei MK, Thiombiano L, Solal-celigny A. 2015. Economic impact assessment of the classical biological control of papaya mealybug in Ghana. 2015. Journal of Agriculture 2:1-18.

Saha R. 2011. Pharmacognosy and pharmacology of Annona squamosa: A review. International Journal of Pharmacy and Life Sciences 2:11831189.

Scott IM, Jensen HR, Philogene BJR, Arnason JT. 2008. Piper spp. (Piperaceae) phytochemistry, insecticidal activity and mode of action. Phytocem Reviews 7:65-75. doi: http://dx.doi. org/10.1007/s11101-006-9058-5.

Sifa A, Prijono D, RaufA. 2013. Keefektifan tiga jenis insektisida nabati terhadap kutu putih papaya Paracoccus marginatus dan keamanannya terhadap larva kumbang predator Curinus coeruleus. Jurnal HPT Tropika 13:124-132.

Townsend ML, Oetting RD, Chong JH. 2000. Management of the mealybug Phenacoccus madeirensis. Proc. South. Nurs. Assoc. Res. Conf. 45:162-166.

Walker A, Hoy M, Meyerdirk D. 2003. Papaya mealybug (Paracoccus marginatus Williams and Granara de Willink (Insecta: Hemiptera: Pseudococcidae). Univ. Florida Featured Creatures. IFAS Extension. Available at: https://edis.ifas.ufl.edu/pdffiles/IN/IN57900. pdf [accessed 15 November 2012].

Williams DJ, Granara MCW. 1992. Mealybugs of Central and South America. Wallingford: $\mathrm{CAB}$ International. 